\title{
Chapter 1 \\ The Place of Civil Society in the Creation of Knowledge
}

\author{
Laura Suarsana, Heinz-Dieter Meyer, and Johannes Glückler
}

This interdisciplinary volume addresses the relations between civil society and knowledge from a social, institutional, and spatial perspective. As knowledge and civil society are co-constitutive (any voluntary civic agency would seem to require a minimum of knowledge and the kinds of civic agency shape the production and use of knowledge), we approach their relationship from two viewpoints: (a) what we know and how we think about the civil society shapes our action in it; (b) the particular relations between knowledge and civil society shape how knowledge in civil society becomes actionable. Adhering to the first imperative, we should carefully reflect and occasionally reconsider our assumptions about civil society. In line with the second imperative, we should carefully distinguish the ways in which civil society impacts knowledge. These range from knowledge creation, its interpretation, and its influence on societal and political discourses to its dissemination through civil society.

This book's authors contribute to the discussion on these relations through conceptual reflections on the role and current developments in civil society as well as through empirical research that yields new insights into these relations. Also, they invite readers and researchers to take new and unconventional perspectives on civil

\footnotetext{
L. Suarsana $(\varangle)$

Institute Labour and Economy, University of Bremen, Bremen, Germany

e-mail: laura.suarsana@uni-bremen.de

H.-D. Meyer

Professor of Education Governance and Policy, Department of Educational Policy and Leadership, University at Albany, State University of New York, Albany, NY, USA

e-mail: hmeyer@albany.edu

J. Glückler

Department of Geography, University of Heidelberg, Heidelberg, Germany

e-mail: glueckler@uni-heidelberg.de
}

J. Glückler et al. (eds.), Knowledge and Civil Society, Knowledge and Space 17,

https://doi.org/10.1007/978-3-030-71147-4_1 
society and offer some outside-the-box perspectives on how civil society can be conceived and analyzed. Conceptual and empirical approaches go beyond the traditional division of the three sectors - market, state, and civil society - to offer inclusive frameworks, and take a broader and more integrative view on civil society and civic agency. In this introduction to the volume, we review selected strands of the contemporary debate and invite readers to examine the role of and relation between civil society and the creation, interpretation, and reproduction of knowledge, followed by a reflection on contemporary perspectives on the civil society concept. Finally, we will outline the book's structure and sketch out the individual contributions to the questions raised in this volume.

\section{Knowledge and Civil Society}

Knowledge has been the focal concept in this book series. Beyond the many conceptualizations of and ascriptions to this term, knowledge denotes the human understanding of concrete and abstract phenomena of the world in which we live. Human understanding differs from data and information in that it is built and rests in people's minds. Whereas bits of data or parcels of commodity can be transferred, knowledge requires comprehension to be translated from one person to the other and from one place to the other. Though being bound to the individual, the creation and interpretation of knowledge remains a relational social process, often collaborative and situated within the confines of symbolic, cultural, and institutional frames (Glückler, Herrigel, \& Handke, 2020; Meusburger, 2008). Hence, learning and knowing are geographically situated and contingent social practices (Bathelt \& Glückler, 2011).

Similarly to the notion of knowledge, the concept of civil society is also contested (Jensen, 2006) and has received contributions from various disciplines in a broad field of study. Researchers of civil society generally address "the diversity and richness of institutions, organizations and behaviors located between the 'market' and the 'state"" (Anheier, Toepler, \& List, 2010, p. V). Civil society encompasses the so-called third or nonprofit sector, which, according to the widely used functional and operational definition of the "Johns Hopkins Third Sector" project, includes organizations that are formal or "institutionalized to some extent," private or "institutionally separate from government," nonprofit-distributing, selfgoverning, and voluntary, "involving some meaningful degree of voluntary participation" (Salamon \& Anheier, 1992, pp. 136-137). Beneath this societal landscape of organizations, practices, and institutions, the concept of civil society is further connected to the public sphere (Calhoun, 2011; Habermas, 1991, 1996), to civic modes of behavior, social movements, or, as an "utopian project," to self-governing democratic coexistence (Adloff, 2005, pp. 8-9).

The relation between civil society and knowledge has several dimensions. Civil society organizations and civic practices are deeply involved in the creation, interpretation, and dissemination of knowledge. 
First, civil society has a role in the creation of knowledge. Through financial or material support and programming priorities, grant-making foundations and associations as well as further nonprofit-organizations are strongly involved in the funding of higher education institutions and research activities (Warren, Hoyler, \& Bell, 2014). Civil society organizations serve as spaces for knowledge production and "democratic innovation" (della Porta \& Pavan, 2017, p. 198). Further, civil society organizations and formally and informally organized individuals themselves are active in innovative social practices and in knowledge creation through research activity and the development of new conceptual approaches and solutions for society, addressing societal challenges in the field of social innovation (Domanski, Howaldt, \& Kaletka, 2020; Howaldt \& Schwarz, 2010; Moulaert, 2016) as well as technology. Researchers increasingly recognize civil society organizations as cocreators of knowledge in regional innovation processes and as elements of innovation systems (Asheim, Grillitsch, \& Trippl, 2017). Scholars in regional governance as well as in international development work consider the local embeddedness and knowledge of civil society actors to be key success factors for locally adapted problem-solving (Christmann, Ibert, Jessen, \& Walther, 2019; Latulippe \& Klenk, 2020; Mistry \& Berardi, 2016). This has led to post-colonial debate on issues of legitimization and power structures as well as to discussions on the relations between different forms of knowledge (Antweiler, 1998; Briggs \& Sharp, 2004, pp. 661-676; see Chap. 10 by Fouksman). In recent decades, new organizational forms such as innovation communities of interest (Brinks \& Ibert, 2015, p. 363), open labs, and makerspaces have emerged as an infrastructure, enabling individuals to independently develop technical solutions, innovations, and prototypes, and to learn through cooperation (Brinks, 2019; Maravilhas \& Martins, 2019). In citizen science, individuals are actively engaged in the advancement of empirical research, collectively collecting or analyzing data (Strasser, Baudry, Mahr, Sanchez, \& Tancoigne, 2019).

Second, civil society actors actively affect and intervene in the interpretation of knowledge, sense-making, and political and societal agenda-setting, hereby influencing public debate and opinion. Civil society as a "locus of political activity" (Cohen \& Arato, 1992, p. XVIII) serves "the articulation, aggregation, and representation of interests" (Diamond, 1994, p. 8). In the conception of civil society as the public sphere, a place of deliberation (Calhoun, 2011; Habermas, 1991, 1996) and an "arena in which political ideas are raised, debated, and decided" (Bob, 2011 , p. 216), civil society serves "to inform its members, and potentially influence the state and other institutions" (Calhoun, 2011, p. 321). With the globalization of communication and digitalization, the public sphere has increasingly shifted from the national to a global level (Castells, 2008). Associations and lobbies bundle interests as well as they advocate in pre- or non-political contexts and within political process (Cohen \& Arato, 1992; Fung, 2003; Hendriks, 2012; Warren, 2011), thereby framing knowledge and (re)interpreting it (Benford \& Snow, 2000, see also Chap. 11 by Chan). Hendriks (2006) distinguishes between formalized fora at a micro-level, where deliberation occurs through "participants from civil society who have relatively unformed and flexible preferences," on one hand and the public 
sphere at the macro-level on the other, as an informal space of "unconstrained communication [...] where public opinion is formed, shaped and contested" (Hendriks, 2006, p. 502). Dodge (2010) finds dualistic strategies of deliberation and transmitting ideas both in cooperation with government within deliberative fora as well as staying critical and autonomously outside of these fora. Further, civil society actors can be elements of epistemic communities, with experts on often global geographical scales sharing a common understanding of knowledge and a "common cognitive framework" (Cohendet, Grandadam, Simon, \& Capdevila, 2014, p. 929; Haas, 1992). From here, actors interpret and transmit knowledge into policy and distribute it into external local contexts (see Chap. 10 by Fouksman). International nongovernmental actors "directly influence domestic educational policies and as they construct a global interpretation of, and set of responses to, worldwide educational "needs"' (Meyer \& Benavot, 2013; Mundy \& Murphy, 2001, p. 85). Further, philanthropists and grant-making civil society organizations exert influence on societal debate with regard to which societal problems they address through their funding, and in their decisions on which topics and selected fields of research they actively support (Clarke, 2019; Frickel et al., 2010; Tompkins-Stange, 2020, see also Chap. 4 by Hess).

Third, civil society organizations are involved in education and the dissemination of knowledge. Worldwide, NGOs and other nonprofit educational institutions offer education and training, providing basic and higher education and adult learning (Meyer \& Boyd, 2001; Priemer, 2015). Cooperation and networks between the state, market, and civil society in the field of education policy have gained increasing importance in the field of global education policy, where they have also raised critical concerns about an emerging deficit of democratic accountability (Ball, 2012; Meyer \& Boyd, 2001; Meyer \& Powell, 2020; Meyer \& Rowan, 2006). In this way, civil society may play constructive roles as innovator in the field of education, but also faces the risk of educational privatization and filling the gaps left by the governmental education system, with philanthropy towards educational institutions covering an increasingly large share of educational finance and thus sometimes gaining asymmetrical influence on educational structures (Archer, 1994; Ball, 2012; Meyer \& Zhou, 2017). Apart from their role in formal education systems, civil society and civic action are expected to provide opportunities to practice, develop, or build civic and citizenship skills, convey democratic values and knowledge of political processes, and to enable and motivate citizens to further political activities (Cohen \& Arato, 1992; Dekker, 2009; Eikenberry, 2009; Foley \& Edwards, 1998, pp. 11-12; Lichterman \& Eliasoph, 2014; Putnam, 2000; Verba, Schlozman, \& Brady, 1995). However, the scope and impact of civil society associations as schools of democracy in a Tocquevillian and neo-Tocquevillian sense, emphasizing the "educative, skill-building, and psychological contributions of associations" (Fung, 2003, p. 517), is subject of discussion (Dekker, 2014, see Chap. 2 by Meyer).

Civil engagement has a geographical dimension as well. The numerous types of organizations and activities discussed in this volume range from activities in specific local and regional contexts to organizations that are integrated in global networks and communities. Apart from the spatial scales of actions and their impacts, 
this volume's authors also illustrate the richness and context-specificity of particular types of civil society, and thus contribute novel insights into civil society's practices and organizations in their relation to knowledge.

\section{Looking for Civil Society in Unexpected Places}

Several authors in this volume have utilized unconventional, innovative, and broader perspectives of civil society, addressing its ephemerality, fragility, and intermediality. In a tradition with a two-century-long pedigree, researchers typically conceive civil society as a place of organizations and associations between market and state, characterized by clearly discernible structures and high amounts of persistence and durability. They also often conceive it as unfolding in the agora of the public sphere, that unambiguous social and physical space in which private actors meet to carry out their business of shared interest. This was particularly obvious when civil society reclaimed widespread intellectual attention in the wake of the events associated with the fall of 1989. Thus, it was two large, formal organizations-the Catholic Church and Solidarnosc in Poland - that supplied the crucial infrastructure in which the cracks of the Soviet Union's empire first became obvious. Likewise, the call "Wir sind ein Volk" [We are one people] was first heard in the former GDR's Protestant churches, the only large social space uncontrolled by a dictatorial government. In both cases, it was large-scale formal organizations that provided arenas of civic associations and energy that played a crucial role in the events leading to the fall of the Berlin Wall and, eventually, the Soviet Empire. In a similar vein, researchers often equate the "third sector" - a frequent connate of the civil society-with "non-governmental and nonprofit organizations."

In this volume, we are attempting to expand the optic on the civil society by foregrounding those less expected and unexpected spaces and geographies in which civil society energies unfold, are blocked, and may re-organize and regroup. In particular, several contributors in this volume suggest that an understanding of the full range of civil society action (and its obstacles) should comprise how civil associations and mobilization takes place in spaces of ephemerality, such as:

- networks, fields, and epistemic communities;

- types of knowledge and ways of doing (or not doing) science;

- by means of often unseen small-scale, grass-roots philanthropy, collective action groups, or rural (but quite "unprovincial") women's associations;

- and through social movements that can be harbingers of civility, but can also overshoot their goal and turn violent and uncivil.

The easy fragility and easy reversal of civility into incivility, and hence, the great fragility of civil society are another theme of this collection of papers. While researchers of civil society have previously tended to emphasize its progressive and democratic potential, the last two decades have brought in their tow many social and political reversals that, we may consider today, have grown into spaces of increased 
inequality and normative and moral heterogeneity that civil society made possible in the first place.

Civil society space, in this perspective, is pre-eminently a social space that may manifest with equal probability as institutional space, virtual space, or physical space. Given the dramatic changes associated with the digital revolution, this is not surprising. Mobilization, organization, and communication - while not limited to the virtual world - are severely hampered if they do not also unfold in cyberspace. Intermediality - both in the sense of multi-mediality (for example, physical and virtual mobilization) and of in-between-ness (e.g., between market and government, or between formal organization and movement) is rapidly becoming a lasting characteristic of civil society. In short, we propose that a useful expansion of our gaze to take in the full range of civil society activities is facilitated by paying greater attention to the ephemeral, fragile, and intermedial nature of civil society processes. Rather than viewing these characteristics as defects or negations of civil society, we may see them as essential aspects and staging grounds of civil society action. In what follows, we flesh out this perspective and offer a brief overview of the chapters included in this book.

\section{The Book's Structure}

The authors of Part I of this volume, (Re-)Thinking Civil Society, reflect on the role of civil society in contemporary societies. Scholars have formulated a broad range of normative expectations towards civil society's role in democratization and deliberation, with sociologists and political scientists intensively discussing this relation both conceptually and empirically (Cohen \& Arato, 1992; Diamond, 1994; Katz, 2006; Walzer, 1995; Warren, 2001). One often finds "the classical liberal, the representative democratic, and the participatory" visions of democratic governance are in contest (Fung, 2003, p. 517). "Contrasting positions highlight that different political theories call on particular kinds of actors within civil society to promote democracy - from individuals, to oppositional groups and social movements, to apolitical associations" (Hendriks, 2006, p. 490). This is accompanied by arguments that civil society's democratic functions are "contingent rather than necessary" (Warren, 2011, p. 378). Undemocratic and uncivil manifestations of civil society are debated (Bob, 2011; Chambers \& Kopstein, 2001; Clarke, 2019) as well as possible contradictions between deliberative democracy and civic activism within civil society as a "site for deliberative politics" (Levine \& Nierras, 2007; Young, 2001, p. 689), all the way to the suggestion that civil society is "a mere abstraction without substance" (Fine, 1997, pp. 7-28).

Heinz-Dieter Meyer (Chap. 2) contributes to this debate, reflecting on the dialectics of civil and uncivil society. Drawing on Tocqueville, he addresses fragilities and vulnerabilities of the civil society and its inherent risks of tipping towards a "gilded" or "bourgeois" society, tending towards despotism. Meyer suggests that we distinguish more carefully between the structural and the normative face of civil society, 
noticing that the two do not necessarily vary together (a structurally robust third sector of the civil society may coexist with a normatively uncivil society). He concludes with a reflection on the possibility that civil society does not generate the kinds of normative constraints and forces needed to maintain it, and points to relevant parallel concerns in the thought of Tocqueville and contemporary theorists like Böckenförde.

Rupert Graf Strachwitz (Chap. 3) discusses the role of civil society as a change agent in contemporary societies, marked by a crisis of capitalism, democracy, and the nation state, as well as growing inequalities. He outlines potentials and limitations of civil society with regards to its possible role in societal development in a globalized world and examines ways by which the interplay between civil society, the state, and the market may be improved. He supports a value-based approach to civil society and emphasizes the necessity of normative principles when looking at civil society organization, as well as the relevance of trustworthiness of civil society organizations as a prerequisite for their functioning as agents for social change.

David J. Hess (Chap. 4) reflects on the relation between knowledge, technology, and civil society. He explores industrial transition movements in the field of energy as a contemporary form of civil society, and discusses subdivisions in this type of social movement. Hess explores the absence of knowledge as "undone science" in emerging technologies, with regard to research on privacy and health risks for the case of smart cities and smart meters. Regarding civil society's connections with politics of knowledge, he outlines how civil society actors may identify areas of undone science, mobilize resources that allow for research in the identified fields, and enable democratic political processes.

The chapters in the second part of this volume, Analyzing Civil Society Organizations, contribute to the knowledge of specific forms of contemporary civil society organizations and offer different approaches to their analysis. Laura Suarsana (Chap. 5) focuses on the LandFrauen organization, a national association of local clubs and associations in Germany. She analyzes the local diversity of civic practices and examines their role in social innovation. Empirically, she illustrates that the LandFrauen make social, cultural and educational offers to address local women's needs in locally specific ways and that they often stimulate social change in the rural areas of Germany. She discusses how the LandFrauen activities are organizationally enabled within vertical and horizontal associational structures and how they are able to adapt to local needs and to initiate social change by interconnecting with the local contexts in which they operate. The deep integration of a large and diverse base of members in rural society empowers the LandFrauen to enact functions as local initiators, catalysts, and multipliers in regional development.

Angela M. Eikenberry (Chap. 6) presents empirically based insights on giving circles as an individualized and informal form of collaborative philanthropic giving and on their influence on their members' civic and political participation. She discusses the role of this emergent form of voluntary associations as schools or pools of democracy, as promoters of civic and political participation, and she discusses how voluntary associations enable their members to develop their skills. 
Johannes Glückler and Jakob Hoffmann (Chap. 7) explore the workings of time banks as a new organizational form of exchanging voluntary services within local communities. Whereas researchers of time banks have often focused on their normative aspects and design principles to strengthen democracy or to facilitate cocreation and reciprocity, the authors observe a lack of knowledge about the processes, mechanisms, and dynamics through which the civic practices as well as the organizational form of time banks actually evolve and operate. Previous researchers have observed an empirical puzzle: Why are time banks so often volatile and short-lived organizations? Based on a detailed case study of a time bank in Southern Germany over a period of 11 years, Glückler and Hoffmann illustrate how using dynamic social network analysis helps convey an understanding of the dynamics of organizational life through the lens of the structure and trajectory of individual practices in a time bank.

In Part III of this book, Spaces, Networks and Fields, the contributors adopt perspectives on civil society with which they challenge common sector-based conceptualizations of civil society or the third sector (Salamon \& Anheier, 1992) as lying between market and state. This perspective has been challenged through empirical observations and conceptualizations that integrate overlaps and hybridization (Anheier \& Krlev, 2014; Evers, 2020; Hasenfeld \& Gidron, 2005; Lichterman \& Eliasoph, 2014), as well as theoretically through approaches such as neoinstitutionalism and network perspectives, contributing to a broader understanding of civil society and extended the research field (Adloff, 2016; Brown \& Ferris, 2007; Burt, 1983; Diani \& McAdam, 2003; Diani \& Pilati, 2011; DiMaggio \& Powell, 1983; Evers, 1995; Faulk, Lecy, \& McGinnis, 2012; Galaskiewicz \& Burt, 1991; Guo \& Acar, 2005; Johnson, Honnold, \& Stevens, 2010; Krashinsky, 1997; Marquis, Glynn, \& Davis, 2007; Marshall \& Staeheli, 2015, see also Chap. 8 by Diani, Ernstson, and Jasny).

Mario Diani, Henrik Ernstson, and Lorien Jasny (Chap. 8) propose an approach with which they integrate conceptualizations of civil society as a discursive and associational space, combining perspectives on both communicative practices and actors. They provide evidence of civil society as networks of issues and associations for the case of food-related issues in the three urban settings of Cape Town, Bristol, and Glasgow. Firstly, they analyze the structure of networks of issues within three civil society organizations in this field, to gain information on their agenda structures and on how they shape public discourse. Secondly, through empirical exploration of inter-organizational civic networks, they focus on the question if and to what extent the prioritization of food-related issues shapes the structure of alliances within civil society networks, and if this increases the probability of collaboration among two organizations.

Johannes Glückler and Laura Suarsana (Chap. 9) draw on the neo-institutional notion of organizational fields and propose the concept of the philanthropic field to conceptualize the geography of giving and the interrelations of benevolent activities across the domains of private, public, and civic sectors. Empirically, they adopt a multimethod approach including a media analysis of reported acts of giving in the German region of Heilbronn-Franconia and provide evidence on the geography of 
giving in this region. Based on their analysis, they suggest that the philanthropic field is constituted by diverse actors from all sectors of society who engage in specialization, division of labor, and collaboration. Moreover, practices of giving spread across geographical scales, though the majority of activity concentrates on the local and regional level.

E. Fouksman (Chap. 10) addresses the formation of epistemic communities and the production of knowledge through discursive geographies and identities with two multi-sited case studies in development-focused civil society organizations in Kenya and Kyrgyzstan. She offers insights into how NGOs adapt and use the categories of local and expert knowledge to defend and promote ideas in order to gain both global authenticity and local authority. She demonstrates how these categories provide positions of power for the individuals which are mobile within development networks and within the organizations, and how knowledge and their positions are used to legitimize local project activities as well as to set agenda in global development discourse.

The authors of Part IV of this book, Doing Civil Society, provide insights into the practices and challenges of contemporary civil society, utilizing theoretical reflections, scientific analyses, and in-depth ethnographic fieldwork on civil society practices.

Kin-man Chan (Chap. 11) draws on his participant knowledge of the prodemocracy Umbrella movement in Hong Kong to discuss how social movements produce and disseminate alternative knowledge as counter-knowledge to dominant discourses. He analyzes the mobilization period from March 2013 to September 2014 and illustrates how the movement set and changed the public agenda. It mobilized public attention to the issue of constitutional reform through creative actions as well as its ability to provide "repertoires of knowledge practices" (della Porta \& Pavan, 2017, p. 300) that allowed for "a common orientation for making claims and acting collectively to produce change" (see Chap. 11 by Chan, p. 237).

Jen Sandler (Chap. 12) offers an approach to broaden the conceptualization of civil society. She argues that civil society is organized and analyzed around silos along lines of organization type, topical focus, and scale, as well as along disciplines. She proposes an integrated perspective of civil society as a set of practices, and hereby focuses on "epistemic activism" projects as cross-field and silo-cutting efforts to produce knowledge and truth and "making it matter." She draws on primary ethnographic fieldwork into civic project meetings of two types of organizations-a civic reform coalition and a social anti-displacement movement- to map epistemic and relational practices and trace the epistemic dimension of civic action.

In his reflection on the \#FeesMustFall movement, Adam Habib (Chap. 13) contributes to the understanding of social movements and the lessons to be learnt regarding the effectiveness of protest and social mobilization for social justice. As the Vice-Chancellor and Principal of the University of the Witwatersrand (Wits) in South Africa during the protests, he illustrates the process of violence increasingly becoming an accepted means within the movement, and interrogates the framing and outcomes of the struggle as well as the associated decision-making processes. He raises the importance of ethical conduct by leaders and activists, concluding that 
social movements must internalize and adapt ethical goals and social justice for sustainable success in social change.

Finally, Heinz-Dieter Meyer (Chap. 14) addresses the question: can there be a civil society without an education that reliably instils norms of civility in the young? What would that education look like? In his chapter on "Civility, Education, and the Embodied Mind-Three Approaches" he argues for a rethinking of education that moves beyond rationalistic conceptions of "head over heart" to one in which head and heart, sentimental and cognitive capacities are in better balance.

\section{Conclusion}

This volume reflects the diversity of civil society-knowledge relations-which we have discussed as knowledge creation, interpretation, and dissemination - and the broad variety of knowledge-related civil society practices and organizations within their specific spatial and socio-economic contexts. The authors adopt different angels to reflect on the reframing, analyzing, and doing of civil society, with some offering new conceptualizations and research perspectives.

Beyond that, this book's contributors reveal the reflexivity of this relation: Civil society plays essential roles in the creation of new knowledge, in the invention of innovative social practices, as well as in education and knowledge dissemination. Enactors of civic practices and civil society organizations generate and reinterpret existing knowledge and introduce it into societal debate or larger epistemic networks. At the same time, civil society is highly dependent on knowledge and information in order to perform its functions. Access to knowledge and information, civil society's capability to gain access, acquire, and create knowledge, as well as to process and reinterpret it, are essential for civil society and civic action and to pursue their objectives.

Present developments that affect contemporary civil society open a perspective on new and perhaps unprecedented ambiguities, ranging from rising concerns about incivility, the emergence of new autocratic regimes, increased hurdles for democracy movements (such as in Hong Kong) and shrinking spaces for civil society (Alscher, Priller, Ratka, \& Strachwitz, 2017; Anheier, Lang, \& Toepler, 2019) to new opportunities through digitalization and new media and the emergence of civil society in unexpected spaces of fields, networks, and communities. There is, also, the still imponderable influence of the coronavirus on everyday life, organizational practice, and civic action: Will our coping with this unprecedented challenge stimulate or chasten and freeze civil society? With regard to what will follow next, we would be glad should this volume contribute to new perspectives and future research on civil society, knowledge, and space. 


\section{References}

Adloff, F. (2005). Zivilgesellschaft: Theorie und politische Praxis [Civil society: Theory and political practice]. Frankfurt: Campus.

Adloff, F. (2016). Approaching philanthropy from a social theory perspective. In T. Jung, S. D. Phillips, \& J. Harrow (Eds.), The Routledge companion to philanthropy (pp. 56-70). Abingdon: Routledge. https://doi.org/10.4324/9781315740324

Alscher, M., Priller, E., Ratka, S., \& Strachwitz, R. G. (2017). The space for civil society: Shrinking? Growing? Changing? Opusculum, 104. Retrieved from https://www.maecenata. eu/2017/09/20/the-space-for-civil-society-shrinking-growing-changing/

Anheier, H. K., \& Krlev, G. (2014). Welfare regimes, policy reforms, and hybridity. American Behavioral Scientist, 58, 1395-1411. https://doi.org/10.1177/0002764214534669

Anheier, H. K., Lang, M., \& Toepler, S. (2019). Civil society in times of change: Shrinking, changing and expanding spaces and the need for new regulatory approaches. Economics: The OpenAccess, Open-Assessment E-Journal, 13, 1-27. https://doi.org/10.5018/economics-ejournal. ja.2019-8

Anheier, H. K., Toepler, S., \& List, R. A. (Eds.). (2010). International encyclopedia of civil society. New York: Springer. https://doi.org/10.1007/978-0-387-93996-4

Antweiler, C. (1998). Local knowledge and local knowing: An anthropological analysis of contested "cultural products" in the context of development. Anthropos, 93, 469-494. Retrieved from https://www.jstor.org/stable/40464844

Archer, D. (1994). The changing roles of non-governmental organizations in the field of education (in the context of changing relationships with the state). International Journal of Educational Development, 14, 223-232. https://doi.org/10.1016/0738-0593(94)90036-1

Asheim, B., Grillitsch, M., \& Trippl, M. (2017). Introduction: Combinatorial knowledge bases, regional innovation, and development dynamics. Economic Geography, 93, 429-435. https:// doi.org/10.1080/00130095.2017.1380775

Ball, S. J. (2012). Global education Inc.: New policy networks and the neo-liberal imaginary. Abingdon: Routledge. https://doi.org/10.4324/9780203803301

Bathelt, H., \& Glückler, J. (2011). The relational economy: Geographies of knowing and learning. Oxford, UK: Oxford University Press. https://doi.org/10.1093/acprof:os obl/9780199587384.001.0001

Benford, R. D., \& Snow, D. A. (2000). Framing processes and social movements: An overview and assessment. Annual Review of Sociology, 26, 611-639. https://doi.org/10.1146/annurev. soc.26.1.611

Bob, C. (2011). Civil and uncivil society. In M. Edwards (Ed.), The Oxford handbook of civil society (pp. 209-219). New York, NY: Oxford University Press. https://doi.org/10.1093/oxfor $\mathrm{dhb} / 9780195398571.013 .0017$

Briggs, J., \& Sharp, J. (2004). Indigenous knowledges and development: A postcolonial caution. Third World Quarterly, 25, 661-676. https://doi.org/10.1080/01436590410001678915

Brinks, V. (2019). 'And since I knew about the possibilities there . . .: The role of open creative labs in user innovation processes. Tijdschrift voor economische en sociale geografie, 110, 381-394. https://doi.org/10.1111/tesg.12353

Brinks, V., \& Ibert, O. (2015). Mushrooming entrepreneurship: The dynamic geography of enthusiast-driven innovation. Geoforum, 65, 363-373. https://doi.org/10.1016/j. geoforum.2015.01.007

Brown, E., \& Ferris, J. M. (2007). Social capital and philanthropy: An analysis of the impact of social capital on individual giving and volunteering. Nonprofit and Voluntary Sector Quarterly, 36, 85-99. https://doi.org/10.1177/0899764006293178

Burt, R. S. (1983). Corporate philanthropy as a cooptive relation. Social Forces, 62, 419-449. https://doi.org/10.1093/sf/62.2.419 
Calhoun, C. (2011). Civil society and the public sphere. In M. Edwards (Ed.), The Oxford handbook of civil society (pp. 311-323). New York, NY: Oxford University Press. https://doi. org/10.1093/oxfordhb/9780195398571.013.0025

Castells, M. (2008). The new public sphere: Global civil society, communication networks, and global governance. The ANNALS of the American Academy of Political and Social Science, 616, 78-93. https://doi.org/10.1177/0002716207311877

Chambers, S., \& Kopstein, J. (2001). Bad civil society. Political Theory, 29, 837-865. https://doi. org/10.1177/0090591701029006008

Chan, K. (2022). Democracy movement and alternative knowledge in Hong Kong. In J. Glückler, H.-D. Meyer, \& L. Suarsana (Eds.), Knowledge and civil society (pp. 235-251). Knowledge and Space: Vol. 17. Cham: Springer. https://doi.org/10.1007/978-3-030-71147-4_11

Christmann, G. B., Ibert, O., Jessen, J., \& Walther, U.-J. (2019). Innovations in spatial planning as a social process: Phases, actors, conflicts. European Planning Studies, 28, 496-520. https://doi. org/10.1080/09654313.2019.1639399

Clarke, G. (2019). The new global governors: Globalization, civil society, and the rise of private philanthropic foundations. Journal of Civil Society, 15, 197-213. https://doi.org/10.108 $0 / 17448689.2019 .1622760$

Cohen, J. L., \& Arato, A. (1992). Civil society and political theory. Cambridge, MA: MIT Press.

Cohendet, P., Grandadam, D., Simon, L., \& Capdevila, I. (2014). Epistemic communities, localization and the dynamics of knowledge creation. Journal of Economic Geography, 14, 929-954. https://doi.org/10.1093/jeg/lbu018

Dekker, P. (2009). Civicness: From civil society to civic services? VOLUNTAS: International Journal of Voluntary and Nonprofit Organizations, 20, 220-238. https://doi.org/10.1007/ s11266-009-9089-9

Dekker, P. (2014). Tocqueville did not write about soccer clubs: Participation in voluntary associations and political involvement. In M. Freise \& T. Hallmann (Eds.), Modernizing democracy: Associations and associating in the 21st century (pp. 45-57). New York: Springer. https://doi. org/10.1007/978-1-4939-0485-3_4

della Porta, D., \& Pavan, E. (2017). Repertoires of knowledge practices: Social movements in times of crisis. Qualitative Research in Organizations and Management, 12, 297-314. https:// doi.org/10.1108/QROM-01-2017-1483

Diamond, L. (1994). Rethinking civil society: Toward democratic consolidation. Journal of Democracy, 5(3), 4-17. https://doi.org/10.1353/jod.1994.0041

Diani, M., Ernstson, H., \& Jasny, L. (2022). Civil society as networks of issues and associations: The case of food. In J. Glückler, H.-D. Meyer, \& L. Suarsana (Eds.), Knowledge and civil society (pp. 149-177). Knowledge and Space: Vol. 17. Cham: Springer. https://doi. org/10.1007/978-3-030-71147-4_8

Diani, M., \& McAdam, D. (2003). Social movements and networks: Relational approaches to collective action. Oxford, NY: Oxford University Press. https://doi. org/10.1093/0199251789.001.0001

Diani, M., \& Pilati, K. (2011). Interests, identities, and relations: Drawing boundaries in civic organizational fields. Mobilization: An International Quarterly, 16, 265-282. https://doi. org/10.17813/MAIQ.16.3.K301J7N67P472M17

DiMaggio, P. J., \& Powell, W. W. (1983). The iron cage revisited: Institutional isomorphism and collective rationality in organizational fields. American Sociological Review, 48, 147-160. https://doi.org/10.2307/2095101

Dodge, J. (2010). Tensions in deliberative practice: A view from civil society. Critical policy studies, 4, 384-404. https://doi.org/10.1080/19460171.2010.525904

Domanski, D., Howaldt, J., \& Kaletka, C. (2020). A comprehensive concept of social innovation and its implications for the local context: On the growing importance of social innovation ecosystems and infrastructures. European Planning Studies, 28, 454-474. https://doi.org/10.108 $0 / 09654313.2019 .1639397$

Eikenberry, A. M. (2009). Giving circles: Philanthropy, voluntary association, and democracy. Bloomington, IN: Indiana University Press. Retrieved from https://muse.jhu.edu/book/3882 
Eikenberry, A. M. (2022). Schools of democracy? Giving circles and the civic and political participation of collaborative philanthropists. In J. Glückler, H.-D. Meyer, \& L. Suarsana (Eds.), Knowledge and civil society (pp. 109-130). Knowledge and Space: Vol. 17. Cham: Springer. https://doi.org/10.1007/978-3-030-71147-4_6

Evers, A. (1995). Part of the welfare mix: The third sector as an intermediate area. VOLUNTAS: International Journal of Voluntary and Nonprofit Organizations, 6, 159-182. https://doi. org/10.1007/BF02353995

Evers, A. (2020). Third sector hybrid organisations: Two different approaches. In D. Billis \& C. Rochester (Eds.), Handbook on hybrid organisations (pp. 294-310). Cheltenham: Edward Elgar. https://doi.org/10.4337/9781785366116

Faulk, L., Lecy, J. D., \& McGinnis, J. (2012). Nonprofit competitive advantage in grant markets: Implications of network embeddedness. Andrew Young School of Policy Studies Research Paper Series, 13-07. https://doi.org/10.2139/ssrn.2247783

Fine, R. (1997). Civil society theory, enlightenment and critique. Democratization, 4, 7-28. https:// doi.org/10.1080/13510349708403499

Foley, M. W., \& Edwards, B. (1998). Beyond Tocqueville: Civil society and social capital in comparative perspective: Editors' introduction. American Behavioral Scientist, 42, 5-20. https:// doi.org/10.1177/0002764298042001002

Fouksman, E. (2022). Global authenticity, local authority: Epistemic power, discursive geographies and the creation of civil society knowledge networks. In J. Glückler, H.-D. Meyer, \& L. Suarsana (Eds.), Knowledge and civil society (pp. 209-232). Knowledge and Space: Vol. 17. Cham: Springer. https://doi.org/10.1007/978-3-030-71147-4_10

Frickel, S., Gibbon, S., Howard, J., Kempner, J., Ottinger, G., \& Hess, D. J. (2010). Undone science: Charting social movement and civil society challenges to research agenda setting. Science, Technology, \& Human Values, 35, 444-473. https://doi.org/10.1177/0162243909345836

Fung, A. (2003). Associations and democracy: Between theories, hopes, and realities. Annual Review of Sociology, 29, 515-539. https://doi.org/10.1146/annurev.soc.29.010202.100134

Galaskiewicz, J., \& Burt, R. S. (1991). Interorganization contagion in corporate philanthropy. Administrative Science Quarterly, 36, 88-105. https://doi.org/10.2307/2393431

Glückler, J., Herrigel, G., \& Handke, M. (2020). On the reflexive relations between knowledge, governance, and space. In J. Glückler, G. Herrigel, \& M. Handke (Eds.), Knowledge for governance (pp. 1-21). Knowledge and Space: Vol. 15. Cham: Springer. https://doi. org/10.1007/978-3-030-47150-7_1

Glückler, J., \& Hoffman, J. (2022). Time banks as transient civic organizations? Exploring the dynamics of decline. In J. Glückler, H.-D. Meyer, \& L. Suarsana (Eds.), Knowledge and civil society (pp. 131-146). Knowledge and Space: Vol. 17. Cham: Springer. https://doi. org/10.1007/978-3-030-71147-4_7

Glückler, J., \& Suarsana, L. (2022). The geography of giving in the philanthropic field. In J. Glückler, H.-D. Meyer, \& L. Suarsana (Eds.), Knowledge and civil society (pp. 179-208). Knowledge and Space: Vol. 17. Cham: Springer. https://doi.org/10.1007/978-3-030-71147-4_9

Guo, C., \& Acar, M. (2005). Understanding collaboration among nonprofit organizations: Combining resource dependency, institutional, and network perspectives. Nonprofit and Voluntary Sector Quarterly, 34, 340-361. https://doi.org/10.1177/0899764005275411

Haas, P. M. (1992). Introduction: Epistemic communities and international policy coordination. International Organization, 46, 1-35. https://doi.org/10.1017/S0020818300001442

Habermas, J. (1991). The structural transformation of the public sphere: An inquiry into a category of bourgeois society. Cambridge, MA: MIT Press.

Habermas, J. (1996). Between facts and norms: Contributions to a discourse theory of law and democracy. Cambridge: Polity.

Habib, A. (2022). Seeding a new world: Lessons from the \#FeesMustFall movement for the advancement of social justice. In J. Glückler, H.-D. Meyer, \& L. Suarsana (Eds.), Knowledge and civil society (pp. 275-290). Knowledge and Space: Vol. 17. Cham: Springer. https://doi. org/10.1007/978-3-030-71147-4_13 
Hasenfeld, Y., \& Gidron, B. (2005). Understanding multi-purpose hybrid voluntary organizations: The contributions of theories on civil society, social movements and non-profit organizations. Journal of Civil Society, 1, 97-112. https://doi.org/10.1080/17448680500337350

Hendriks, C. M. (2006). Integrated deliberation: Reconciling civil society's dual role in deliberative democracy. Political Studies, 54, 486-508. https://doi.org/10.1111/j.1467-9248.2006.00612.x

Hendriks, C. M. (2012). The politics of public deliberation: Citizen engagement and interest advocacy. London: Palgrave Macmillan. https://doi.org/10.1057/9780230347564

Hess, D. J. (2022). Undone science and smart cities: Civil society perspectives on risk and emerging technologies. In J. Glückler, H.-D. Meyer, \& L. Suarsana (Eds.), Knowledge and civil society (pp. 57-73). Knowledge and Space: Vol. 17. Cham: Springer. https://doi. org/10.1007/978-3-030-71147-4_4

Howaldt, J., \& Schwarz, M. (2010). Social innovation: Concepts, research fields and international trends. Dortmund: Sozialforschungsstelle Dortmund.

Jensen, M. N. (2006). Concepts and conceptions of civil society. Journal of Civil Society, 2, 39-56. https://doi.org/10.1080/17448680600730934

Johnson, J. A., Honnold, J. A., \& Stevens, F. P. (2010). Using social network analysis to enhance nonprofit organizational research capacity: A case study. Journal of Community Practice, 18, 493-512. https://doi.org/10.1080/10705422.2010.519683

Katz, H. (2006). Gramsci, hegemony, and global civil society networks. VOLUNTAS: International Journal of Voluntary and Nonprofit Organizations, 17, 332-347. https://doi.org/10.1007/ s11266-006-9022-4

Krashinsky, M. (1997). Stakeholder theories of the non-profit sector: One cut at the economic literature. VOLUNTAS: International Journal of Voluntary and Nonprofit Organizations, 8, 149-161. https://doi.org/10.1007/BF02354192

Latulippe, N., \& Klenk, N. (2020). Making room and moving over: Knowledge co-production, indigenous knowledge sovereignty and the politics of global environmental change decisionmaking. Current Opinion in Environmental Sustainability, 42, 7-14. https://doi.org/10.1016/j. cosust.2019.10.010

Levine, P., \& Nierras, R. M. (2007). Activists' views of deliberation. Journal of Public Deliberation, 3, 4. https://doi.org/10.16997/jdd.48

Lichterman, P., \& Eliasoph, N. (2014). Civic action. American Journal of Sociology, 120, 798-863. https://doi.org/10.1086/679189

Maravilhas, S., \& Martins, J. (2019). Strategic knowledge management in a digital environment: Tacit and explicit knowledge in Fab Labs. Journal of Business Research, 94, 353-359. https:// doi.org/10.1016/j.jbusres.2018.01.061

Marquis, C., Glynn, M. A., \& Davis, G. F. (2007). Community isomorphism and corporate social action. Academy of Management Review, 32, 925-945. https://doi.org/10.5465/ amr.2007.25275683

Marshall, D. J., \& Staeheli, L. (2015). Mapping civil society with social network analysis: Methodological possibilities and limitations. Geoforum, 61, 56-66. https://doi.org/10.1016/j. geoforum.2015.02.015

Meusburger, P. (2008). The nexus of knowledge and space. In P. Meusburger, M. Welker, \& E. Wunder (Eds.), Clashes of knowledge: Orthodoxies and heterodoxies in science and religion (pp. 35-90). Knowledge and Space: Vol. 1. Dordrecht: Springer.

Meyer, H.-D. (2022a). The dialectic of civil and uncivil society-Fragility, fault lines, and countervailing forces. In J. Glückler, H.-D. Meyer, \& L. Suarsana (Eds.), Knowledge and civil society (pp. 19-42). Knowledge and Space: Vol. 17. Cham: Springer. https://doi. org/10.1007/978-3-030-71147-4_2

Meyer, H.-D. (2022b). Civility, education, and the embodied mind-Three approaches. In J. Glückler, H.-D. Meyer, \& L. Suarsana (Eds.), Knowledge and civil society (pp. 291-308). Knowledge and Space: Vol. 17. Cham: Springer. https://doi.org/10.1007/978-3-030-71147-4_14

Meyer, H.-D., \& Benavot, A. (Eds.). (2013). Pisa, power, and policy: The emergence of global educational governance. Oxford Studies in Comparative Education: Vol. 23. Didcot: Symposium. https://doi.org/10.15730/books.85 
Meyer, H.-D., \& Boyd, W. L. (2001). Education between state, markets, and civil society: Comparative perspectives. Mahwah: Lawrence Erlbaum Associates. https://doi. org/10.4324/9781410602114

Meyer, H.-D., \& Powell, J. J. (2020). New institutionalism in higher education. In M. E. David \& M. J. Amey (Eds.), The SAGE encyclopedia of higher education (pp. 1084-1089). Vol. 3. Thousend Oaks: Sage. https://doi.org/10.4135/9781529714395.n405

Meyer, H.-D., \& Rowan, B. (2006). The new institutionalism in education. New York, NY: SUNY Press.

Meyer, H.-D., \& Zhou, K. (2017). Autonomy or oligarchy? The changing effects of university endowments in winner-take-all markets. Higher Education, 73, 833-851. https://doi. org/10.1007/s10734-017-0109-1

Mistry, J., \& Berardi, A. (2016). Bridging indigenous and scientific knowledge. Science, 352, 1274-1275. https://doi.org/10.1126/science.aaf1160

Moulaert, F. (2016). Social innovation: Institutionally embedded, territorially (re)produced. In D. MacCallum, F. Moulaert, J. Hillier, \& S. V. Haddock (Eds.), Social innovation and territorial development (pp. 11-24). Abingdon: Routledge. https://doi.org/10.4324/9781315609478

Mundy, K., \& Murphy, L. (2001). Transnational advocacy, global civil society? Emerging evidence from the field of education. Comparative Education Review, 45, 85-126. https://doi. org/10.1086/447646

Priemer, J. (2015). Zivilgesellschaftliches Engagement für Bildung [Civil societal engagement for education]. Essen: SV Wissenschaftsstatistik gGmbH im Stifterverband für die Deutsche Wissenschaft. Retrieved from http://ziviz.de/publikationen/bildungsstudie_2015

Putnam, R. D. (2000). Bowling alone: America's declining social capital. In L. Crothers \& C. Lockhart (Eds.), Culture and politics: A reader (pp. 223-234). New York: Palgrave Macmillan. https://doi.org/10.1007/978-1-349-62965-7_12

Salamon, L. M., \& Anheier, H. K. (1992). In search of the non-profit sector. I: The question of definitions. VOLUNTAS: International Journal of Voluntary and Nonprofit Organizations, 3, 125-151. https://doi.org/10.1007/BF01397770

Sandler, J. (2022). Epistemic activism in the United States: Examining meetings across the silos of civil society. In J. Glückler, H.-D. Meyer, \& L. Suarsana (Eds.), Knowledge and civil society (pp. 253-273). Knowledge and Space: Vol. 17. Cham: Springer. https://doi. org/10.1007/978-3-030-71147-4_12

Strachwitz, R. G. (2022). Civil society as an agent of change. In J. Glückler, H.-D. Meyer, \& L. Suarsana (Eds.), Knowledge and civil society (pp. 43-56). Knowledge and Space: Vol. 17. Cham: Springer. https://doi.org/10.1007/978-3-030-71147-4_3

Strasser, B. J., Baudry, J., Mahr, D., Sanchez, G., \& Tancoigne, E. (2019). "Citizen science”? Rethinking science and public participation. Science \& Technology Studies, 32(2), 52-76. https://doi.org/10.23987/sts.60425

Suarsana, L. (2022). Specialists for crumble cakes? The German LandFrauen organizations in social innovation and as educational, social, and political institutions. In J. Glückler, H.-D. Meyer, \& L. Suarsana (Eds.), Knowledge and civil society (pp. 77-107). Knowledge and Space: Vol. 17. Cham: Springer. https://doi.org/10.1007/978-3-030-71147-4_5

Tompkins-Stange, M. E. (2020). Policy patrons: Philanthropy, education reform, and the politics of influence. Cambridge, MA: Harvard Education.

Verba, S., Schlozman, K. L., \& Brady, H. E. (1995). Voice and equality: Civic voluntarism in american politics. Cambridge, MA: Harvard University Press.

Walzer, M. (1995). The concept of civil society. In M. Walzer (Ed.), Toward a global civil society (pp. 7-28). Providence: Berghahn.

Warren, A., Hoyler, M., \& Bell, M. (2014). Strategic cultures of philanthropy: English universities and the changing geographies of giving. Geoforum, 55, 133-142. https://doi.org/10.1016/j. geoforum.2014.06.006

Warren, M. E. (2001). Democracy and association. Princeton, NJ: Princeton University Press.

Warren, M. E. (2011). Civil society and democracy. In M. Edwards (Ed.), The Oxford handbook of civil society (pp. 377-390). New York, NY: Oxford University Press. https://doi.org/10.1093/ oxfordhb/9780195398571.013.0030 
Young, I. M. (2001). Activist challenges to deliberative democracy. Political Theory, 29, 670-690. https://doi.org/10.1177/0090591701029005004

Open Access This chapter is licensed under the terms of the Creative Commons Attribution 4.0 International License (http://creativecommons.org/licenses/by/4.0/), which permits use, sharing, adaptation, distribution and reproduction in any medium or format, as long as you give appropriate credit to the original author(s) and the source, provide a link to the Creative Commons license and indicate if changes were made.

The images or other third party material in this chapter are included in the chapter's Creative Commons license, unless indicated otherwise in a credit line to the material. If material is not included in the chapter's Creative Commons license and your intended use is not permitted by statutory regulation or exceeds the permitted use, you will need to obtain permission directly from the copyright holder. 